\title{
CONTEMPORARY APPROACHES TO COMPENSATING Female TORT VICTIMS FOR INCAPACITY TO WORK
}

\author{
ELIZABETH ADJIN-TETTEY
}

This article explores the developing area of the compensation of female tort victims. This area has been marked by the under-compensation of female victims. The author examines some of the reasons for this under-compensation. The author also addresses recent attempts by the judiciary to eliminate any gender bias or stereotypical assumptions about women when assessing damages for incapacity to work.
L'article explore l'indemnisation de femmes victimes de délits civils, domaine en voie de développement. Ce domaine a été marqué pour la sous-indemnisation des femmes victimes. L'auteur étudie certaines des causes de cette sousindemnisation. L'auteur se penche également sur des essais récents faits par le pouvoir judiciaire pour éliminer le sexisme ou les hypothèses stéréotypées au sujet des femmes au moment de lëvaluation des dommages pour incapacité de travail.

\section{TABLE OF CONTENTS}

I. ASSESSING COMPENSATION FOR

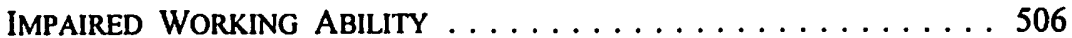

II. GENDER BIAS AND STEREOTYPICAL ASSUMPTIONS ABOUT WOMEN'S WORK . . . . . . . . . . . . . . . . . 509

III. REDRESSING GENDER BIAS IN ASSESSING

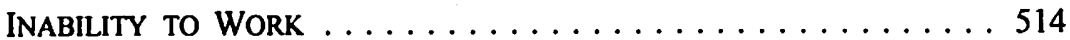
A. ACTUARIAL DATA USED IN

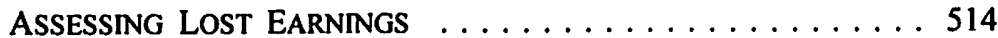
B. IMPLICATIONS OF MARRIAGE ON
WOMEN'S EARNINGS $\ldots \ldots \ldots \ldots \ldots \ldots \ldots \ldots \ldots$
C. COMPENSATION FOR

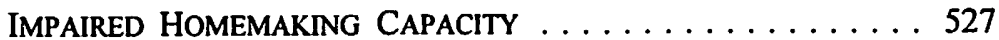

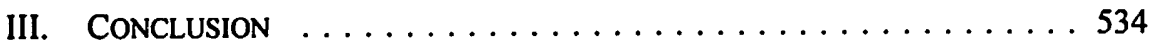

Traditionally, Canadian courts have awarded global amounts to compensate victims of tortious injuries. Further, Canadian courts do not have to specify amounts awarded for the various heads of damages. The current trend is to itemize the various heads of pecuniary damages and the amount recoverable under each head. In Andrews v. Grand and Toy Alberta, 'the Supreme Court of Canada approved the itemization approach as a principled method of assessing general damages. The itemization approach enables tort victims to be assessed not only on the heads of damages considered in the case, but also on amounts awarded for the various heads recognized by the courts in personal 
injury claims. ${ }^{2}$ The itemization approach has revealed specific areas where gender bias influences the assessment of damages in personal injury claims.

Historically, a gender bias has worked to the disadvantage of females awarded compensation for inability to work due to tortious injury. Gender plays an important role in determining the value of a woman's lost earnings or, more generally, of her inability to work. The assessment of inability to work is futuristic; courts rely on actuarial data of persons in the plaintiff's category (usually determined by gender) to arrive at fair and just compensation. Females have been disadvantaged by this process in several ways. The value of lost earning capacity for women with no prior work history tends to be fixed close to the poverty line. ${ }^{3}$ Women who were part of the labour force at the time of their injury do not necessarily escape this gender discrimination because female earnings tend to be lower than male earnings due to pay inequality between men and women. Consequently, female plaintiffs end up with lower awards than male plaintiffs when courts use female earning statistics. Likewise, the "marriage contingency" has been evoked to reduce damage awards for women. Marriage is perceived to have had an adverse impact on the earning capacity of women, as women are more likely to leave the workforce, among other things, for child-bearing and child-rearing purposes. Women were awarded no monetary compensation for impaired housekeeping abilities because they were not paid for work done in the home. This aspect of the law of personal injury has rightly been denounced as discriminatory against women and as unjust and in serious need of reform. This article examines recent judicial attempts to eliminate gender bias in awarding damages for impaired working capacity in personal injury claims. The subject of inquiry is referred to as "working capacity" because of the recent trend to compensate victims not just for lost earnings but also for impaired ability to perform household tasks. This article argues that this is a sound categorization because it makes it possible to compensate women for the inability to work regardless of where this work takes place.

This article begins by looking at the purpose of compensating tort victims for impaired ability to work, and the method of assessing damages under this head of damages. The analysis in this section focuses on ability to work as it is traditionally understood. I argue that the emphasis on earnings or participation in the waged labour force partly explains the depressed awards received by women. Women may have different work patterns than men and the location of their work may differ. Thus women may not lend themselves to the neat categorization of the "model participant" of the work force. Next, the article discusses some stereotypical assumptions about women's work and the extent to which these biases have influenced the assessment of damages for the inability to work. The article then assesses recent judicial developments

2 In personal injury claims, courts award compensation for special and general damages. Special damages consist of pre-trial pecuniary losses incurred by the victim as a result of the accident. General damages include cost of future care, loss of prospective earnings (which is referred to in this article as compensation for incapacity to work), and non-pecuniary losses for pain and suffering.

3 See Arnold v. Teno, [1978] 2 S.C.R. 287, 83 D.L.R. (3d) 609 [hereinafter Arnold, cited to D.L.R.]; Fenn v. City of Peterborough, [1981] 2 S.C.R. 613. 
that redress past inequities against women and young females in the determination of damages for impaired working capacity resulting from tortious injury.

\section{ASSESSING COMPENSATION FOR IMPAIRED WORKING ABILITY}

The working capacity of personal injury victims may be wholly or partially impaired due to accident. The compensatory principle in tort law requires that defendants restore their victims to their pre-accident state. ${ }^{4}$ Thus, plaintiffs whose ability to work has been impaired are compensated for that loss. The purpose of the head of damage of inability to work is to compensate victims for pecuniary losses arising from the injury by replicating the pre-accident working life of the victim insofar as monetary compensation can accomplish this. Courts compute lost earnings based on the severity of the injury and on the extent to which the victim's ability to work has been impaired. This is assessed on the basis of the victim's pre-accident working lifespan. ${ }^{5}$ In the absence of evidence indicating the probability of early retirement or death, the assessment is based on a retirement age of 65 years.

What courts seek to achieve under the head of damages of impaired working ability is the subject of debate. ${ }^{6}$ As Cassels points out, "[t]he choice is usually said to be between two options: (a) placing a value upon the actual probable earnings that have been lost as a result of the accident; or (b) placing a value upon the diminished earning capacity of the victim." The prevailing view appears to be that the earning capacity approach is the appropriate basis for this head of damage. In 1978, the Supreme Court of Canada stated its preference for this approach in a trilogy of cases dealing with personal injuries. ${ }^{8}$ In Andrews, the plaintiff was rendered a quadriplegic in a traffic accident. In assessing his prospective loss of earnings, the Supreme Court of Canada emphasized that the plaintiff was being compensated for his earning capacity as opposed to for mere earnings. Dickson J. stated, "It is not the loss of earnings but, rather, loss of earning capacity for which compensation must be made... A capital asset has been lost: what was its value?" "Lost earning capacity is considered a present loss of a capital asset. ${ }^{10}$ The courts must, therefore, determine the value of this asset at the time of the injury.

See Andrews, supra note 1 at 241; J. Cassels, Remedies: The Law of Damages, (Toronto: Butterworths, 2000) at 13, 43, 52; Linden, Canadian Tort Law, 2d ed. (Toronto: Butterworths, 1997) at 4.

This is contrasted with compensation for cost of future care which is calculated on the basis of the post-accident life span of the plaintiff.

See K.E. Cooper-Stephenson \& I.B. Saunders, Personal Injury Damages in Canada, 2d ed. (Toronto: Carswell, 1996) at 205-206; J. Cassels, "Damages for Lost Earnings: Women and Children Last!" (1992) 71 Can. Bar Rev. 445 at 447-49; S.M. Waddams, The Law of Damages, 2d ed. (Toronto: Canada Law Books, 1991) para. 3.710.

Cassels, ibid. at 447 [emphasis in original].

The three cases are Andrews, supra note 1; Thornton v. School Dist. No. 57 (Prince George), [1979] 2 S.C.R. 267; and Arnold, supra note 3.

Supra note 1 at 251.

Ibid. 
Ascertaining the value of the lost asset can be a challenging exercise as courts must predict the victim's future losses. Part of the difficulty stems from the fact that human capital has no market value. Consequently, the appropriate measure of compensation can only be speculative. Courts use the salary level of the victim at the time of the injury as a starting point. Courts consider factors that could have increased the plaintiff's probable earnings such as the "chance of future promotion, career changes, productivity increase and other positive contingencies" 11 including pay equity considerations. Similarly, courts consider factors that might adversely affect a particular victim's actual earning potential and reduce the award to reflect those negative contingencies. ${ }^{12}$

The method adopted in practice by the courts to compute the value of the lost asset appears to be inconsistent with the theory underlying the lost earning capacity approach. Courts award compensation based on what a plaintiff would have earned had the injury not occurred. ${ }^{13}$ This was evident in Andrews, where the Court fixed the value of the plaintiff's lost asset based on his projected level of earnings. The Court awarded $\$ 1,200$ per month, a figure in-between his salary level at the time of the injury and the maximum salary for his type of work.

Subsequently, courts have interpreted the Supreme Court of Canada's assessment in the trilogy to mean that an attempt should be made to compensate plaintiffs for what they would have earned but for their injury. In Tucker (Public Trustee of) v. Asleson, ${ }^{14}$ the plaintiff was eight years old at the time of the accident. She suffered serious head injuries with severely disabling consequences. The trial judge found that she was totally disabled from gainful employment. ${ }^{15}$ In assessing compensation for the impairment of the plaintiff's ability to earn income, McEachern C.J.B.C. affirmed that the proper interpretation of the trilogy on this point is to compensate the plaintiff for what she would have earned but for her injuries. ${ }^{16}$ McEachern C.J.B.C. stated that the court's task is to attempt to compensate the plaintiff for her lost earning capacity, but recognized that this could not be achieved by simply assessing the victim's capacity in the air $;^{17}$ capacity must be considered in relation to other relevant factors. McEachern C.J.B.C. maintained that the theoretical basis for the award must be kept distinct from the method of assessment. ${ }^{18} \mathrm{He}$ also points out that, inasmuch as the courts "strive for social justice," their assessment of lost earnings must be based on "realistic predictions

Cassels, supra note 6 at 448. See also Waddams, supra note 6 at para. 3.720 .

See Cooper-Stephenson \& Saunders, supra note 6 at 375-76, Cassels, ibid. at 453.

See D. Réaume, "Rethinking Personal Injury Damages: Compensation for Lost Capacities" (1988) 67 Can. Bar Rev. 82 at 85-88.

(1993), 78 B.C.L.R. (2d) 173 (C.A.) [hereinafter Tucker].

Ibid. at 226, para. 153.

lbid. at 226-27, paras. 155-56.

Ibid. at 227, para. 156.

Ibid. at 226-27, paras. 155-56. 
about the future." 19 The net result is that a plaintiff is in fact compensated for what they would have earned. ${ }^{20}$

Similarly, in Johnson v. Zenith, ${ }^{21}$ Lambert J.A. emphasized that the lost earnings approach is the proper means of assessing the value of a plaintiff's loss. The plaintiff, a 33-year old woman, suffered a brain injury in a motor vehicle collision. The plaintiff held a Bachelor of Arts degree and a diploma in Social Work. She had worked in numerous social work positions and was employed at the time of the accident as a counsellor with an annual income of about $\$ 21,000$. Her ability to work was seriously impaired and she could no longer perform at her pre-accident capacity. At issue in this case, inter alia, was the proper principle for assessing future loss of earnings. Lambert J.A. emphasized that "it is the loss of capacity that is being assessed," but maintained that "[t]he prognostication must be made about what the plaintiff would have earned had the accident not occurred."22

Thus, regardless of the terminology employed by the courts to describe this head of damages, what courts actually do is compensate victims for what they would have earned but for their injury. ${ }^{23}$ If the lost asset theory advocated in Andrews is understood to mean compensation only for the value of the asset that the plaintiff would have put to productive use, then the difference between the two approaches is merely semantic.

Cooper-Stephenson and Saunders point out that earning capacity appears to be relevant only in cases where the plaintiff had chosen to work under their maximum capacity or to accept a lesser salary and where that situation was likely to have continued into the future. ${ }^{24}$ Where this trend is not expected to continue throughout

Ibid. at 232, para. 179.

20 See Cassels, supra note 6 at 448. The case of Knoblauch v. Biver Estate, [1992] 5 W.W.R. 725 (Sask. Q.B.) [hereinafter Knoblauch] provides an example of judicial preference for the earnings approach in determining the value of a plaintiff's loss, if any. In Knoblauch, the plaintiff was a 51 -year-old farm housewife who worked exclusively on the farm. Occasionally, the plaintiff spoke of seeking work outside the farm, but she took no positive steps toward that purpose. She suffered severe whiplash in a car accident. The court denied her claim for past and future loss of earnings. Based on the plaintiff's educational level (grade 8), lack of skills, and age, the court said there was no reasonable probability of her seeking a job outside the farm. Given these circumstances, Noble J. said (ibid. at 737) that "it is not fair to conclude she has suffered an actual loss of earning capacity because her talk of going out to work can be seen as self-serving at this point in time if it is not backed up with evidence of something more." The plaintiff was, however, compensated for loss of housekeeping capacity and inability to perform farm work. (1995), 61 B.C.A.C. 222 (C.A.).

Ibid. at 227, para. 18. See also MacCabe v. Board of Education of Westlock Roman Catholic Separate School District No. 110 (1999), 226 A.R. 1 [hereinafter MacCabe] at 111, para. 477 where Johnstone J. affirmed the earning capacity approach.

23 Cooper-Stephenson and Saunders argue that compensation under this head of damage, for the most part, is based on projected earnings. In support of this view, they point out that diminution of damages based on negative contingencies speaks to what a person would have earned and not earning capacity as the basis for assessing the appropriate measure of the plaintiff's loss: supra note 6 at $212-16$.

lbid. at 216-19. 
the plaintiff's entire working life, the courts must adjust the award to reflect this possibility by way of positive contingencies. This method of assessment is consistent with the earnings approach as it seeks to compensate a victim for what they would have earned but for the accident. Presumably, the earning capacity approach could result in over-compensation in such circumstances. Historically, this line of reasoning was used to justify depressed awards for injured women and girls. Reliance on differential earnings for men and women was seen as a reflection of reality, not as reinforcing systemic discrimination against women. Likewise, application of "the marriage contingency" and its negative impact on women's earnings was seen as a realistic assessment of their probable earnings, and, therefore, as just. The next section looks at some stereotypical assumptions that have worked to the detriment of women in personal injury claims.

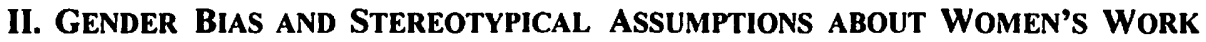

The lost earnings method assesses the value of a plaintiff's loss in relation to its market value. This is partly why there are difficulties when the plaintiff was not participating in the waged labour market at the time of the injury. This is a gendered problem because injured women and girls often fall into this category. This method values productive activity based on its location. Activities that take place in the public sphere are assigned a monetary value, whereas the same activity does not attract a similar valuation if it occurs in a private home. The result has been the economic invisibility of housework and also the devaluation or non-valuation of housework in personal injury claims. ${ }^{25}$

The conceptual difficulties in this area of the law are attributable partly to the historical bifurcation between the public and private spheres, and to the neutrality and/or disinterest of the law in the private realm of the home. The historical association of women with the private realm militates against their visibility and potential in the "public" sphere. It also helps to construct and reinforce the perception of men as breadwinners for the nuclear family. Consequently, women are not perceived to be breadwinners or heads of households. ${ }^{26}$ When women participate in the paid labour force, their income is seen as secondary and as a supplement to the husband's income. The message is that women's income is dispensable. Therefore, there is no need to value what women do (particularly in the home) in monetary terms. Moreover, the wage gap between men and women is viewed as natural. ${ }^{27}$

The perception of women as secondary wage earners leads to the devaluation of women's work both in and out of the home. The traditional stereotypical conceptions of the family (in particular the role of women) disadvantages women in personal injury

See Cassels, supra note 6 at 446-47.

Except, of course, when the husband is deceased. Even then, the expectation was that the woman would remarry or be taken care of through her widow's pension.

E. Gibson, "The Gendered Wage Dilemma in Personal Injury Damages" in K.D. CooperStephenson \& E. Gibson, eds., Tort Theory (North York, Ont.: Captus University Publications, 1993) 185 at 200. 
compensation in two principal ways. First, it operates as a negative contingency on damage awards from the perspective of the plaintiff in that it reduces the amount recoverable for loss of probable earnings. Historically, courts considered marriage as a negative contingency on future earnings of women. The assumption was that women leave the workforce for child-bearing and child-rearing purposes. Consequently, they would have limited (if any) attachment to the labour force upon getting married. This had a tremendous impact on compensation for lost future earnings for women, especially in cases involving young female victims.

Along with the myth of the male-headed household as the dominant form of social ordering, the assumption remains that female victims would most likely have married and would not have worked outside the home. This was clearly evident in Arnold. ${ }^{28}$ In Arnold, the four-and a half-year old female plaintiff suffered catastrophic injuries as a result of being struck by a passing car after purchasing ice cream from a parked ice cream truck. Spence J. fixed her prospective loss of income close to the poverty level (at $\$ 6,000$ per year). In justification of the award, Spence J. noted that it is extremely difficult for courts to assess prospective earnings for children of such a young age. He stated: "There can be no evidence whatsoever which will assist us in determining whether she ever would have become a member of the work force or whether she would have grown up in her own home and then married."29 Spence J. was not willing to give the plaintiff the benefit of the doubt by assuming that she would at least have followed in her mother's footsteps and become a primary school teacher. ${ }^{30}$ This would have entitled her to a higher compensation than she in fact received. The British Columbia Court of Appeal applied similar contingencies in Tucker fifteen years later. Southin J.A., speaking for the majority of the Court, said that there was no guarantee that the intellectual and economic promise that the plaintiff exhibited at the time of injury would have been realized. ${ }^{31}$ Among other things, Southin J.A. noted that those aspirations could have been marred due to marriage and to having children. ${ }^{32}$

Admittedly, the assessment of loss of future income is, for the most part, extremely speculative. It is at best guesswork and has been referred to judicially as "crystal ball gazing." ${ }^{33}$ This is even more applicable in the case of injured children where the courts are guided by little or no evidence about their future work patterns. However, male children appear to get more favourable treatment in this regard than do female children. In regard to young boys, the assessment often turns on how well or how poorly the plaintiff would have fared in the workforce. On the other hand, for young females, the choice tends to be between homemaking or participation in the waged labour force. In Taylor v. Bristol Omnibus, ${ }^{34}$ Denning, M.R. commented on the difficulties in assessing lost future earnings for young plaintiffs. He stated:

\footnotetext{
Arnold, supra note 3.

Ibid. at 636.

Ibid.

Tucker, supra note 14, at 214-15, para. 94.

Ibid.

MacCabe, supra note 22 at 110 , para. 475.

[1975] 2 All E.R. 1107 (C.A.).
} 
Who can say what a baby boy will do with his life? He may be in charge of a business and make much money. He may get into a mediocre groove and just pay his way... It is even more speculative with a baby girl. She may marry and bring up a large family, but earn nothing herself. Or, she may be a career woman, earning high wages. ${ }^{35}$

There is, furthermore, no judicial recognition of monetary gain made by women when they marry. Consequently, female victims are not perceived to have suffered financial losses for the loss of an opportunity to form such a relationship. At best, the diminution of the opportunity to enter into any such relationship is considered under the head of "loss of amenities," and is considered a positive factor in assessing nonpecuniary damages. ${ }^{36}$ This is intended to compensate women for the loss of enjoyment that they would otherwise have derived from marriage. This would not necessarily increase damage awards for women because courts are cautious in awarding nonpecuniary damages where a functional approach is favoured. The purpose is to provide the injured person with reasonable solace for her or his misfortune. Solace is usually taken to mean physical arrangements that will make the injured party's life more bearable. ${ }^{37}$ Based on the difficulties of translating non-pecuniary losses into monetary terms, Canadian courts tend to resist excessive awards in this area. The functional approach generally enables the judiciary to moderate damage awards by insisting that non-pecuniary awards should be fair to both parties and that plaintiffs deserve no more than what is needed to ameliorate their condition. To this end, the Supreme Court of Canada capped non-pecuniary damages at $\$ 100,000$ (1978 dollars adjusted to reflect inflation) in the trilogy. ${ }^{38}$ This was subsequently affirmed in Lindal v. Lindal where Dickson J. noted that a higher award would be "rare indeed." ${ }^{39}$ In ter Neuzen v. Korn, Sopinka J. was of the view that the trilogy had imposed a legal limit to non-pecuniary damages and that a higher award would be excessive as a matter of law..$^{40}$ Clearly, the consideration of loss of opportunity to form a relationship of financial interdependency under non-pecuniary damages is not likely to result in just compensation for female tort victims.

Second, women are disadvantaged by the societal undervaluation of homemaking services. This has resulted in the under-compensation of women for loss of working capacity. Women's participation in the paid labour force could be interrupted not only by child-bearing and child-rearing but also by other responsibilities such as general family care. Women received no monetary recognition for these services in the valuation of lost earning capacity. The non-valuation of homemaking services has disadvantaged women because no monetary value was accorded for what women did outside the waged labour force.

Ibid. at 1113 .

In the trilogy, the Supreme Court of Canada recognized that non-pecuniary losses include loss of amenities.

See Andrews, supra note 1 at 262, per Dickson J.

lbid. at 265 where Dickson J. stated: "I would adopt as the appropriate award in the case of a young adult quadriplegic like Andrews the amount of $\$ 100,000$. Save in exceptional circumstances, this should be regarded as an upper limit of non-pecuniary loss in cases of this nature."

[1981] 2 S.C.R. 629 [hereinafter Lindal] at 642-43.

[1995] 3 S.C.R. 674 [hereinafter ter Neuzen] at 722-23, para. 106. 
Today, women are becoming increasingly visible in the paid labour force, and this trend is likely to continue. ${ }^{41}$ This has not, however, resulted in ameliorating the conceptual invisibility and/or the ghettoization of women in the labour force. ${ }^{42}$ As well, the wage difference between men and women continues to be a problem in contemporary Canadian society, and is unlikely to be eliminated by formal equality. ${ }^{43}$ Gibson points out that this discrimination is the result of complex sociological factors that define and constrain women's roles:

Women are constrained at present by societal roles. Primary responsibility for childrearing, homemaking, and extended family obligations provides Canadian women with less time on average to devote to wage labour and inclines them toward lower-paying but more flexible work arrangements.

The typical workplace is set up to function based on traditional male labour arrangements in terms of hours of work, job security, seniority (women take time out and are disadvantaged by such interruptions as maternity leave).... As well, traditional male models of competence ... networking and hierarchical relationships disadvantage women's opportunities for promotion. ${ }^{44}$

Women continue to be disadvantaged to the extent that courts use female earning statistics in assessing lost earnings. These figures discriminate against women because they tend to be lower than male earnings. Most importantly, since female statistics are based on the actual historic earnings of women, their use implies approval of the

See G. Picot \& A. Heisz, "The Labour Market in the 1990s" (2000) 13(2) Canadian Economic Observer 3.8 at 3.12; Statistics Canada, Canadian Economic Observer Statistical Summary (Ottawa: Statistics Canada, June 2000) at 15-16; P. Khosla, Review of the Situation of Women in Canada (Toronto: National Action Committee on the Status of Women, 1993) at 3; CooperStephenson \& Saunders, supra note 6 at 293.

In a study commissioned by the National Action Committee on the Status of Women, Khosla notes that while there is public optimism about the increasing participation of women in the paid work force, the vast majority of women work in the lowest paying sectors of the economy: ibid. See also P. Armstrong \& H. Armstrong, The Double Ghello: Canadian Women and their Segregated Work, 3d ed. (Toronto: McClelland \& Stewart, 1994) at 15; H. Barnett, Sourcebook on Feminist Jurisprudence (London: Cavendish Publishing, 1997) at 8-9; and B. Ziff, Principles of Property Law, 2d ed. (Scarborough: Carswell, 1996) at 77, where he notes that although women have participated in the paid labour force in unprecedented numbers, they rarely hold executive positions. He attributes this to the operation of "a 'glass ceiling' which impedes women's advancement within corporate structures."

In Public Service Alliance of Canada v. Canada (Treasury Board) (July 1998) TD 7/98 (C.H.R.C.), the Canadian Human Rights Commission upheld a longstanding complaint by the complainant that government employees in predominantly female job categories did not receive equal pay for work of equal valuc. The tribunal ordered the Treasury Board to adjust the salaries of employees in the affected job categories to reflect their value relative to jobs performed mostly by men. The Federal Government's application for a judicial review of the pay equity decision was dismissed by the Federal Court: see Public Service Alliance of Canada v. Canada (Treasury Board) (1999), 180 D.L.R. (4th) 95 (F.C.T.D.). Barnett notes that the wage disparity between women and men continues even where women participate in predominantly male occupations. She cites the example of Canada where women have made significant inroads into male-dominated areas such as administration, management, engineering, and physical sciences, yet women earned 15 to 20 percent less than their male counterparts: ibid. at 9 . Picot and Heisz confirm this fact by noting that the earning inequality among women and men did not change much between mid-1980 and mid-1990: supra note 41 at 3.15 . 
historical wage disparity between men and women. Reliance on female eaming tables is also problematic because they do not reflect women's actual capacity in the past or in the future. ${ }^{45}$ The ostensible justice inherent in this approach (it is perceived to be an actual reflection of socio-economic conditions in the society) obscures the injustice it replicates and perpetuates. Stereotypical assumptions about women and their work are ignored in the process. The approach does not question the wage differential between men and women. As well, it accepts the under-valuation of work done, mostly by women, outside the paid labour force. Gibson claims that the gendered approach to assessing compensation for personal injury is not only flawed but may be also illegal as it has been found to contravene human rights legislation and the Canadian Charter of Rights and Freedoms. ${ }^{46}$ The assessment of damages must be consistent with Charter principles. Therefore discriminatory awards on the basis of a prohibited ground such as sex may be illegal and the judiciary should not consider the plaintiff's gender in determining the appropriate compensation for inability to work. Though the majority of the Supreme Court of Canada ruled in Dolphin Delivery ${ }^{47}$ that the Charter does not apply to private litigation based on the common law, they nevertheless held that Charter principles remain relevant to the resolution of such claims. McIntyre J. stated that: "the judiciary ought to apply and develop the principles of the common law in a manner consistent with the fundamental values enshrined in the Constitution.... [T] Charter is far from irrelevant to private litigants whose disputes fall to be decided at common law." ${ }^{\prime 8}$ Consequently, whereas a Charter right cannot be asserted against a private individual or entity, the adjudication of common law causes of action between purely private litigants must reflect Charter principles as the expression of public policy. ${ }^{49}$ In MacCabe, ${ }^{50}$ the Alberta Court of Queen's Bench emphasized that the assessment of damages in personal injury claims must be consistent with the Charter principle of equality. Johnstone J. stated "I will not sanction the 'reality' of pay inequity. The societal trend is and must embrace pay equity given our fundamental right to equality which is entrenched in the constitution. ${ }^{51}$ And, later Johnstone J. stated "[e]quality is now a fundamental constitutional value in our society."

Fortunately, gender bias in compensating accident victims for their inability to work has not gone unnoticed. Recent case law shows an effort by the courts to reverse this deplorable situation and to achieve just results for all tort victims regardless of gender. The next section looks at the contemporary approaches to ascertaining the value of

See S.A. Griffin, "The Value of Women - Avoiding the Prejudice of the Past" (1993) 51 Advocate 545 at 548.

See Gibson, supra note 27 at 203-207. See s. 15(1) of the Canadian Charter of Rights and Freedoms, Part I of the Constitution Act, being Schedule B to the Canada Act, 1982, (U.K.), 1982, c.11 [hereinafter Charter], which guarantees individuals equality before and under the law and equal protection and benefit of the law. R.W.D.S.U., Local 580 v. Dolphin Delivery Lid., [1986] 2 S.C.R. 573.

Ibid. at 603. 
female victims' incapacity to work and the extent to which gender has been eliminated in these assessments.

\section{REDRESSING GENDER BIAS IN ASSESSING INABILITY TO WORK}

The case law is now showing a more principled, egalitarian approach to the treatment of women and girls. The starting point was the recognition that women have historically been disadvantaged in the assessment of lost earning capacity for tort victims, and that this is partly due to inequities that have worked to the detriment of women. A number of factors are identified in this journey for justice for injured women and girls. This article focuses on the following three areas and the extent to which they eliminate gender bias against women in personal injury claims: (a) the actuarial statistics employed in assessing loss of earning capacity; (b) the impact of marriage on a woman's earnings; and (c) the valuation of homemaking services.

\section{A. Actuarial Data Used in AsSessing Lost Earnings}

Past inequities in personal injury compensation stemmed partly from earning statistics relied on in assessing the value of the accident victim's loss. Courts used female earning statistics as the basis for compensating women without recognizing the discriminatory effect of wage differentials between men and women. At the very least, this relegated women to the category of second-class citizens inferior to men. Increasingly, Canadian courts are not only acknowledging gender biases regarding wages but are also taking steps to remedy this situation. To achieve this result, courts rely on one of two approaches. The first is to use female earning tables and gross up the award to increase and equalize the salaries of women to those of men. The second approach is to use male earning statistics and discount it by the contingencies thought to be appropriate.

\section{USE OF Female EARNINGS WITH PossibILITY OF TOP-UP}

The starting point for this approach is the use of female statistics. However, courts are mindful of the flawed nature of female statistics, inter alia, because they are premised on wage disparity between men and women and on stereotypical assumptions about women's participation in productive labour. Courts are now aware that the use of female earning tables result in lower awards for female tort victims. Consequently, female earning tables are not treated as the ultimate determinants of lost income but simply as a starting point, thereby leaving the possibility for upward adjustments. Courts are beginning to take account of factors that might increase the value of a woman's loss by way of positive contingencies (such as pay equity initiatives and the financial benefits of a relationship of interdependence) to justify higher awards for female tort victims. This trend is particularly noticeable in the assessment of damages for young girls and women who might benefit from wage parity in their lifetimes. This 
approach was favoured by McEachern J.A. in Tucker. ${ }^{53}$ In particular, he noted that courts should accord proper weight to identifiable societal trends in the labour market in order that future loss of income reflect relevant future circumstances. ${ }^{54}$ As well, the award should not be discounted for negative contingencies because these are already accounted for in the average statistics. To the contrary, the award may be enhanced if evidence is admitted that suggests the likelihood of the plaintiff exceeding the average performance.

The female earnings approach constituted the basis for assessing the young female plaintiff's lost earnings in Cherry (Guardian ad litem of) v. Borsman. ${ }^{\text {ss }}$ In Cherry, the infant plaintiff was born with severe disabilities because of an unsuccessful abortion. The trial judge assessed the plaintiff's lost earnings based on two years of postsecondary education for women. On appeal, the plaintiff argued that using male earnings would better reflect her loss because by the time she would have entered the labour force, wage disparity between men and women would have been eliminated or diminished. Though the British Columbia Court of Appeal recognized that the trial judge could have enhanced the award to reflect the changing place of women in the work force, it opined that no revisable error was committed by the trial judge's failure to do so.

This approach received the approval of the Supreme Court of Canada in ToneguzzoNorvell (Guardian ad litem of) v. Burnaby Hospital. ${ }^{56}$ In Toneguzzo-Norvell, the infant appellant suffered severe disabilities due to oxygen deprivation at birth. The appellant's condition was expected to persist throughout her life. The trial judge accepted the appellant's contention that compensation for her lost earnings should be based on earnings of women with post-secondary, non-university education. Male earning statistics introduced in evidence were only meant to be used for comparative purposes and were therefore disregarded by the trial judge in the assessment of lost earnings. The British Columbia Court of Appeal affirmed the trial judge's disposition of this issue. On appeal to the Supreme Court of Canada, counsel for the appellant argued that the award for lost future earnings should be based on male earning statistics. McLachlin J., as she then was, speaking for the Court, affirmed the method adopted by the trial judge in using female wage statistics and in increasing the amount to reflect the diminishing wage differential between males and females. ${ }^{57}$

Supra note 14 at 233 , para. 183 . Indeed, he notes that using average incomes of universityeducated males as the starting point was not an accurate reflection of the plaintiff's loss. This is because only a small percentage of the population completes university. It is the use of this inaccurate starting point that necessitated the application of a large contingency deduction (63 percent) to reflect the risk that the plaintiff might not obtain a university degree: ibid. at 230 , paras. 166-68.

ss (1992), 16 B.C.A.C. 93 (C.A.) [hereinafter Cherry], leave to appeal to S.C.C. refused (1993), 32 B.C.A.C. 79.

36 [1994] I S.C.R. 114 [hereinafter Toneguzzo-Norvell].

57 lbid. at 124. 
Theoretically, this decision is consistent with the probable earnings approach as it allows the court to consider realistic probabilities of future changes in order to arrive at what a victim would have earned but for her injury. ${ }^{58}$ However, this method is flawed to the extent that it does not challenge current pay inequity. Rather, it accords judicial sanction to a system that discriminates against women. ${ }^{59}$ It also unnecessarily increases the burden on plaintiffs by requiring them to adduce in evidence "identifiable societal trends"60 that would enhance their future losses. This leaves the issue of topup to the discretion of judges, creates uncertainty, and allows for differential outcomes for injured young females depending on evidence presented to the court. The British Columbia Court of Appeal's refusal to intervene in the assessment of lost earnings in Cherry ${ }^{61}$ illustrates some of the difficulties that female plaintiffs could face because of reliance on the female earnings approach. This approach cannot be relied on to achieve satisfactory results for all victims. The strength of evidence adduced, how such evidence is presented, and judicial discretion will determine the outcome in individual cases.

\section{USE of MALE EARNINGS WITH APPROPRIATE CONTINGENCY DEDUCtions}

A noticeable trend in assessing lost earnings for injured women and girls is for the court to use male earning statistics and discount the awards by the appropriate contingencies. ${ }^{62}$ In Toneguzzo-Norvell, the plaintiff argued that relying on female earning tables in assessing her lost earnings was flawed and that the Court should substitute an award based on male earning statistics. Though the Supreme Court refused to vary the award, ${ }^{63}$ the Court did not rule out the possibility of using male earning tables when they are properly introduced and are supported by evidence. Consequently, the Supreme Court of Canada has left the door open for the use of male tables in assessing lost earnings for women and girls.

The decision of the Supreme Court of Canada in Toneguzzo-Norvell implicitly affirms the use of male tables applied in an earlier decision. The use of male statistics for young female victims had been upheld by the majority of the British Columbia

See Cooper-Stephenson \& Saunders, supra note 6 at 212-13.

In Toneguzzo-Norvell, supra note 56 at 124, McLachlin J. (as she then was) viewed the trial judge's recognition that female earnings tables reflect past inequities against women as a step in the right direction.

As per McEachern C.J.B.C. in Tucker, supra note 14 at 232, para. 180.

Cherry, supra note 55.

This must be distinguished from gender-neutral earning tables that make use of average earnings for men and women because those statistics are still skewed by the wage disparity based on gender.

McLachlin J. was of the view that the Supreme Court of Canada could not entertain the plaintiff's argument to use male earning tables because this evidence was not before the trial court. The only evidence before the trial judge was the female earning table. Though counsel for the plaintiff had alluded to male tables in the course of submissions, this was intended for comparative purposes only and was not to be relied upon. Since the trial judge did not err in relying on female tables, there was no justification for the Supreme Court of Canada to interfere with the damage award: Toneguzzo-Norvell, supra note 56 at 123-25. 
Court of Appeal in Tucker. ${ }^{64}$ In Tucker, the infant plaintiff, an eight-year old girl, sustained catastrophic injuries in a motor vehicle accident. She suffered severe head injuries with disabling consequences. Her doctors did not expect her to be gainfully employed in the future. In assessing her lost earnings, Finch J. relied on average, university-educated British Columbia male earnings (statistically shown to be $\$ 947,000)$. Having adopted this progressive approach that values earning capacity based on potential rather than gender, the trial judge then discounted the award by a surprisingly large 63 percent to reflect negative contingencies. The plaintiff ended up with $\$ 350,000$ for lost earnings. The majority of the British Columbia Court of Appeal declined to interfere with this assessment. ${ }^{65}$

In Terracciano (Guardian ad litem of) v. Etheridge, ${ }^{66}$ Saunders J. endorsed the use of male earning tables as the starting point for assessing the lost earning capacity of the female plaintiff because they reflected a realistic approximation of her loss. The plaintiff (a sixteen-year old girl in grade 11) sustained catastrophic injuries in a motor vehicle accident. The Court accepted that the evidence showed that the plaintiff was an average student who had held a number of part-time jobs since her early teenage years. The trial judge rejected the defendants' argument that female and not male earnings ought to be used as the appropriate measure of the plaintiff's loss of future income. Instead, Saunders J. held that the reliance on average male earning statistics, with at least one-year post-secondary education, was the proper way of assessing the plaintiff's lost earnings. ${ }^{67}$ Saunders J. reasoned that, based on the plaintiff's work history, family work ethic, and strong family influence, the male earning model was a realistic reflection of the plaintiff's loss. ${ }^{68}$

Feminist scholars favour relying on average male earning statistics because they are free from gender bias and can, therefore, yield better results for women. ${ }^{69}$ This trend may be in response to concern that the use of gendered statistics for assessing lost earnings violates the Charter and human rights legislation. This trend may also reflect societal recognition of historical inequities and may be seeking to bridge the wage gap between men and women. Ostensibly, this approach is progressive, gender-neutral, and could be a better reflection of lost earning capacity of female victims. However, its actual application can be problematic. As well, the result may be no different from the results reached using gendered earning statistics. These problems were clearly evident in the Tucker decision where the court applied a huge contingency deduction to the award. Tucker certainly casts doubt on the fairness of this method of valuation. The male earnings data approach relies on average earnings for the group of which the plaintiff is considered a member. As Cassels points out, average earnings are based on actual earnings of members of the relevant group. ${ }^{70}$ Adverse factors that might

Tucker, supra note 14.

Ibid. at 213-15, paras. 86-97.

(1997), 33 B.C.L.R. (3d) 328 [hereinafter Terracciano] at 350, paras. 86-87 (Q.B.).

lbid. at 350 , para. 86.

Ibid. at 350 , para. 87.

See E. Gibson, "Loss of Earning Capacity for Female Tort Victims: Comment on Toneguzzo-

Norvell (Guardian ad litem of) v. Burnaby Hospital' (1994) 17 C.C.L.T. (2d) 78 at 95-96.

Cassels, supra note 6 at 454. 
diminish earnings such as illness, accidents, unemployment, and other vicissitudes of life are already incorporated in these tables. ${ }^{11}$ Thus, the application of further negative contingencies to awards based on average earnings could constitute double discounting and is, therefore, unwarranted. ${ }^{72}$ It disregards the fact that such considerations are already included in the average earnings statistics. Women are also disadvantaged by the fact that, when made, judicial contingency deductions for injured females far exceed those made for males. ${ }^{73}$ The obvious result of this approach is under-compensation for injured women and girls. ${ }^{74}$

The use of male tables ${ }^{75}$ in assessing lost working capacity appears to work better for injured women with strong attachment to the paid labour market (or at least when there are clear indications of a career path at the time of the injury) than for very young females. In $\mathrm{MacCabe}{ }^{76}$ a 16-year old grade 11 student was rendered a quadriplegic as a result of injury she sustained in gymnastics class. Following the accident, the plaintiff completed high school and obtained a Bachelor of Recreational Administration, graduating with high grades. The plaintiff was pursuing a post-graduate degree program in health promotion at the time of the trial. Notwithstanding her educational accomplishments, the Court found that the result of the accident was that the plaintiff had suffered significant limitations which affected her employability. The Court held that, but for her accident, the plaintiff would have completed a university degree in physiotherapy and secured employment in a hospital setting. The Alberta Court of Queen's Bench chose to use male earning tables as the basis for assessing her lost earnings. The Court was convinced that, prior to the accident, the plaintiff had exhibited characteristics and abilities that would have placed her on an equal footing with her male counterparts. ${ }^{77}$ Based on this evidence, Johnstone J. concluded that the plaintiff's lost earnings would be comparable to males in her chosen profession. ${ }^{78}$ In arriving at this decision, it was anticipated that the plaintiff would not have withdrawn significantly from the paid labour force for childbirth and/or for child-rearing purposes. ${ }^{79}$ Once this had been established and accepted by the Court, the Court accepted that the value of the plaintiff's loss was comparable to her male counterparts and refused to sanction the historical wage disparity that exists between men and women. $^{80}$

lbid.

McEachern J.A. recognized this in Tucker, supra note 14 at 233, para. 183, when he states that it is not necessary to discount average earnings based on negative contingencies because they are already reflected in the average figures.

See Cassels, supra note 6 at 453-54; Gibson, supra note 69 at 84-85.

The 63 percent discount rate in Tucker, supra note 14, may be extreme. It can be explained by the use of male tables as the starting point. Conventional deductions range from 10 to 37 percent depending on the evidence adduced by plaintiff. See Gibson, ibid.

Male tables for the plaintiff's particular or anticipated career.

Supra note 22.

lbid. at 109, para. 468.

lbid. at 111, para. 481.

Ibid.

See also Terracciano, supra note 66 at $349-50$, paras. $79-88$ for a similar analysis regarding the probable earnings of a 16-year old plaintiff. 
Similarly, in Zibrik v. Sams, ${ }^{81}$ the 28-year-old plaintiff was an accountant with a very bright future at the time of her accident. Her employment history was excellent. There was evidence that she had upgraded her skills in the past, and was in fact, at the time of the accident, completing the course necessary to become a Certified Management Accountant. Her intention was to complete a Bachelor of Commerce degree. Though the plaintiff intended to raise a family, there was evidence that this would not result in substantial interruption in her employment. Hunter J. favoured the use of male earning tables because the plaintiff's future loss would be closer to male earnings than to female earnings. He stated that the plaintiff's job aspirations and her experience did not reflect jobs chosen particularly by women.

Once a court has decided that it is appropriate to assess a female plaintiff's loss based on male earnings, it can insist (as was done in $\mathrm{MacCabe}{ }^{82}$ ) on refusing to apply female-specific contingencies to the damage award. As already noted, damages for lost earnings are subject to contingencies such as illness, unemployment, and job loss that could affect a person's working life. Johnstone J. recognized that recently there has been a significant improvement in women's participation in the paid labour force. As this trend is expected to continue into the future, a woman's working life is now comparable to a man's. As such, the application of gender-specific contingencies in assessing damages is unwarranted. Just like the earning statistics used in calculating lost earnings, the contingencies applied to the award should not be determined by the victim's gender.

Cases that rely on male earnings as the appropriate measure of a female plaintiff's lost earnings are premised on a particular assumption about the nature of women's participation in the waged labour force. The male earnings approach is often justified, inter alia, on the ground that the plaintiff would not have taken significant time out of the workforce for child-bearing and child-rearing purposes. Implicit in this line of reasoning is the assumption that homemaking services have no value. This is because "full" compensation for injured women is justified based on their anticipated participation in the paid labour force, usually supported by an indication that there would not be any substantial interruptions in the plaintiff's employment for childbearing and child-rearing purposes. This may be inconsistent with recent decisions that compensate victims both for the inability to participate in the paid labour force and for the inability to perform homemaking services. ${ }^{83}$

It is important to note that while this approach may reflect current and future circumstances regarding employment patterns of, and opportunities for, females as well as regarding pay equity, there is doubt as to whether it achieves fair results, particularly for defendants. The argument is that the use of male tables in the valuation of lost

"1 (24 March 1997), Kamloops, 18872 (B.C.S.C.).

*2 Supra note 22 at 110 , para. 470.

*1 For examples, see Fobel v. Dean (1991), 83 D.L.R. (4th) 385 (Sask. C.A.) [hereinafter Fobel]; and McLaren v. Schwalbe (1994), 148 A.R. I (Q.B.) [hereinafter McLaren], where the plaintiffs were awarded damages for lost earnings and inability to perform homemaking services. 
income is not a reflection of "reality," and, therefore, could inflate women's awards. ${ }^{84}$ The unwillingness of courts to use male earning tables is noticeable in cases involving young female victims because of a lack of evidence that would enable the courts to make realistic predictions about their future income. This appears to follow from the emphasis on the nature of a female plaintiff's attachment to the paid work force and/or on individual characteristics that would have enabled the plaintiff to compete equally with her male counterparts.

Given that equality between men and women is a protected constitutional right in Canadian society, it can safely be argued that there are no impediments to job opportunity based on gender. As well, the introduction of pay equity legislation and the current societal trends to bridge the wage gap between men and women mean that, in the future, male and female earnings will be comparable. Consequently, the ultimate determinant of the value of a plaintiff's loss ought to be individual characteristics and capabilities. In Terracciano, Saunders J. commented on the inappropriateness of compensating accident victims on the basis of gender: "I am doubtful of the propriety, today, of this Court basing an award of damages on a class characteristic such as gender, instead of individual characteristics or considerations related to behaviour." 85 Arguably, this approach is consistent with the restitutio in integrum principle underlying compensation in tort. Indeed, in cases where the courts sanctioned the use of male earning tables, the individual characteristics of the plaintiffs which made their employment capabilities comparable to men were used to justify the use of that approach. This is apparent in Tucker where the victim was eight years old at the time of the accident. In affirming the use of male wage statistics to assess her lost earnings, the majority of the British Columbia Court of Appeal made references to her apparent intellectual and economic promise at the time of injury. Southin J.A., speaking for the Court, noted that the plaintiff "is not and never will be in mind or spirit the person she showed the promise of becoming." ${ }^{186}$ Once this determination is made, the use of male tables becomes the proper method of ascertaining the victims' losses because, as Saunders J. pointed out in Terracciano, that would be a better approximation of the realistic life earnings lost by the victims.

Reliance on individual characteristics to ascertain lost earnings has as its the purpose just compensation. Unfortunately, this cannot be a universal panacea for the injustices that women face in personal injury compensation. This approach is based on the victim's attachment to the paid work force and/or on capabilities exhibited at the time of the injury. Although this may be a fair way of assessing lost earnings for women

For instance, in Tucker, supra note 14 at 232-33, paras. 179-82. McEachem J.A. dissenting, found that the sad reality, as indicated by current statistics, is that women earn far less than men. Though he found this to be deplorable, he states that this reality must not be ignored, because to do otherwise would be unfair to the defendant. He proposed that average female earnings should be used to compute the loss of young females and average male earnings for young males. He noted that the most the courts can do in the face of such disparity between lost earnings for young females and males is to accord proper weight to identifiable societal trends in the labour market so that future loss of income reflects relevant future circumstances.

86 Tucker, supra note 14 at 213 , para. 87. 
with a work history (as this is traditionally understood), it cannot be relied on in cases involving victims with no history of participation in the paid labour force. Likewise, it cannot be used for victims with no educational qualifications, no promise of attaining such qualifications, or simply those too young to have exhibited characteristics that could lead the court to reasonably predict their employment patterns. Though the court in Tucker considered the young plaintiff's intellectual and economic promise in affirming the use of male earning tables, the plaintiff's young age may partly explain the huge contingency deduction applied in that case. In the view of the British Columbia Court of Appeal, there was not enough evidence to establish whether or not the victim would have achieved her apparent potential. ${ }^{87}$

The trial court in Mulholland (Guardian ad litem of) v. Riley Estate ${ }^{88}$ reached a similar conclusion. In Mulholland, the trial judge noted that it may be dangerous to assess the value of a future wage loss based merely on the victim's aspirations when the person who has expressed them is too young to have realized their goals. In this case, the 15-year old plaintiff sustained a closed head injury in a motor vehicle accident. Her ability to work was severely diminished. In assessing her future income, the British Columbia Court of Appeal agreed that the male earnings profile is to be preferred, yet refused to interfere with the trial judge's use of a figure set between the values in the male and female tables. ${ }^{89}$

Gender remains an important factor in assessing lost earnings for very young tort victims. ${ }^{90}$ This trend is evident in recent cases where judges have refused to follow the judicial view that the use of male earning statistics is the most realistic approximation of the loss suffered by female plaintiffs. For instance, in Webster v. Chapman," the infant plaintiff suffered birth defects due to the defendant doctor's negligence for failure to warn the mother about the risk of foetal abnormalities associated with the consumption of coumadin during pregnancy. The child-plaintiff was born with severe mental and physical disabilities. She was unable to sit up on her own or to talk, and was not expected to progress past the level of a one-year old. The Court concluded, based on family history and circumstance, that the child would have completed her high school education. The Court calculated the value of her lost earnings based on average incomes of females in Canada with that level of education. ${ }^{92}$ As was discussed above, these statistics discriminate against females and perpetuate wage inequity between males and females. The decision in Webster ignores legislative and judicial efforts towards pay equity and ignores the hope that parity of earnings between men and women would be achieved by the time the young plaintiff would have entered the waged labour force (or, at least, during her working life). As well, the Court's decision assumes that the plaintiff would have worked in a femaledominated occupation. Because the injury occurred in utero, the plaintiff could not have

Ibid. at 214-15, paras. 93-95.

(1996), 12 B.C.L.R. (3d) 248 (C.A.) [hereinafter Mulholland].

lbid. at 262, paras. 45-46.

See Griffin, supra note 45 at 545.

[1996] 6 W.W.R. 652 (Man. Q.B.) [hereinafter Webster].

lbid. at 700 . 
indicated any specific career choice(s) at the time of the injury. Since persons with a high school education work in a variety of occupations, the court's choice of female earning statistics is questionable and seems retrogressive.

Some courts have been less explicit about their choice of gendered earnings in assessing future earnings, though this is implicit in their decisions. Such was the case in Lusignan (Litigation Guardian of) v. Concordia Hospital. ${ }^{93}$ There, the female infant plaintiff suffered brain damage at birth. As a result, she was severely mentally handicapped and also suffered a mild degree of cerebral palsy. The Manitoba Court of Queen's Bench was presented with evidence on the present value of lost income for men and for women. At trial, the judge failed to make an explicit choice between male and female earnings in the assessment of lost earnings for the young female victim. Instead, Jewers J. chose to shroud the basis of valuation in mystery and opted for a lower figure without offering any explanation. Presumably, Jewers J. was influenced by the use of female statistics in Webster (to which he referred to immediately preceding his conclusion on lost income). This may have been a way for the court to conceal its preference for female earning statistics in assessing the value of the plaintiff's lost earnings.

In sum, courts have made some effort not to replicate and perpetuate gender inequality in the assessment of lost earnings for injured females. Using female earning tables with the possibility of top-up appears progressive but is not entirely satisfactory. The use of male tables is regarded as a better way to assess lost earnings inasmuch as it is devoid of gender bias. However, the propriety of assessing the value of one's loss based solely on gender is questionable. ${ }^{94}$ This approach violates Charter principles and human rights legislation. The suggestion of using individual characteristics and capabilities to assess lost earnings appears attractive as employment is presumably based on characteristics such as educational qualifications, experience, and other personal attributes. Unfortunately, this method is also unsatisfactory because it does not provide the basis for assessing damages in all cases. Reliance on individual characteristics could reinforce the historical bias against certain groups of women on the basis of such factors as race, socio-economic class, and physical ability. As Gibson notes, "the less the victim's gender, race and socioeconomic background approximate those of the decision-maker, the more prejudices and stereotypes factor into the equation, and the less accurate becomes the projection."95 As well, it leaves intact the problem of assessing lost earnings for plaintiffs who have left no indication of the nature of their participation in the paid labour force at the time of accident.

There are no easy solutions to the problem of assessing lost earnings for injured female tort victims. In light of the diversity of female tort victims, there can be no "one-size fits all" solution to the valuation of the lost earnings problem. The appropriate approach ought to be determined based on the facts of the case and on the pre-accident situation of the victim. In general, individual characteristics, capabilities, and potential 
should inform the courts' assessment of the value of lost earnings. This must be done in a way that does not perpetuate past inequities. Where there is evidence of past earnings or of future potential, the male average earnings for the job sector should be chosen. Where the victim is too young to determine what their employment potential is, the average male figure for all wage earners should be used.

\section{B. IMPLiCations OF MARRIAGE ON WOMEN'S EARNingS}

As pointed out in Section II, marriage was perceived to have a detrimental impact on women's earnings. Courts used the "marriage contingency" to justify a reduction in awards for lost earnings for women and not for men. A change in judicial perception in Canada was signalled by Anderson J.A. in Blackstock v. Patterson. ${ }^{96}$ In that case, the plaintiff-respondent suffered severe injuries in an automobile accident resulting in substantial permanent disability. She was engaged to be married at the time of the accident. In assessing the plaintiff's loss of future earning capacity, the trial judge considered negative contingencies that would diminish her earnings, including the probability of marriage. As well, the trial judge opined that she would not have reaped any significant financial benefits from her marriage and, therefore, refused to make an upward adjustment to her award for that purpose. Consequently, there was no reason to adjust her award upward or downward to reflect the loss of an opportunity to marry. On appeal, the plaintiff-respondent argued that the trial judge applied wrong principles in computing her loss of future earning capacity. Anderson J.A. recognized that the loss of opportunity to marry could warrant an upward or downward adjustment of damage awards, provided there is a sound evidential basis for doing so. No such adjustment was warranted in her case because there was no statistical information upon which the adjustment could be made.

The Blackstock decision signalled that marriage could have both positive and negative effects on a person's earnings. The proper place of marriage in the assessment of damages for personal injury victims was fully recognized by Lambert J.A. in Reekie v. Messervey. ${ }^{97}$ In Reekie, the 21-year-old plaintiff was injured in an automobile accident which rendered her a complete paraplegic. The Court found that there was about a 90 percent probability that she would have married in her mid-20s and that she would have moved in and out of the labour force at various times for the remainder of her working life. The Court, however, found that the shared benefits of conjugal life would have continued at all times, though at different levels. Consequently, the trial judge awarded her $\$ 50,000$ for the loss of opportunity to marry. The underlying principle, together with the award for loss of an opportunity to marry, was sustained on appeal. However, Lambert J.A. questioned the propriety of separating this sub-head of damage (loss of an opportunity to marry) from the general head of lost future earnings. He preferred instead a composite approach in which the impact of the loss of shared family income on the plaintiff's earnings is considered by way of contingencies. Lambert J.A. pointed out that marriage, and more generally long-term relationships of interdependency, have interconnected pecuniary consequences. 
[T] here is both a pecuniary and non-pecuniary aspect to loss of opportunity to form a permanent interdependency relationship. The proper course is to consider the non-pecuniary aspect in the award for non-pecuniary damages, and the pecuniary aspect in the award for other pecuniary losses. Care must be taken to distinguish the two and care must be taken to avoid double compensation.... 'Lost opportunity of family income' deals only with the financial aspects of the loss of an opportunity to form such a relationship. ${ }^{\text {s8 }}$

In support of this position, Lambert J.A. reasoned that the claim under consideration was based on the compensatory principle by which plaintiffs are entitled to be compensated for all of their pecuniary losses arising from the accident. ${ }^{99}$

This decision is a departure from the prevailing assumptions about the effect of marriage on a woman's financial status. The Supreme Court of Canada affirmed this principled approach to assessing an accident victim's pecuniary loss in ToneguzzoNorvell. The Supreme Court commended the lower court judge for recognizing that the inability of the infant victim to form a relationship of interdependence due to her injury constitutes a pecuniary loss and warrants compensation. ${ }^{100}$ However, as the trial record could not support a proper consideration of the loss of opportunity to benefit from shared family income, there was no adjustment to the award of damages. ${ }^{101}$

The assessment of ability to form a relationship of interdependence is relevant in situations where the prospect of a shared living arrangement has been detrimentally affected by the injury. This is a welcome inroad into the assessment of damages for female tort victims because of its potential to increase compensation for pecuniary losses. This progressive position is partly attributable to the changing societal perception of marriage as a partnership. ${ }^{102}$ It recognizes women's contribution to the overall financial situation of the family unit, regardless of the location of their work. As well, this new judicial thinking reflects the social reality that people do live together and benefit from shared "family" income without necessarily being married in the traditional sense. Compensation under this sub-head is justifiable in spite of the observation that the "traditional family unit is disintegrating" because of the increasing tendency to adopt less of a permanent couple lifestyle. ${ }^{103}$ Emphasis should be placed on partnership, or more broadly, on live-in relationships in which people share their resources. Indeed, as stated by Lambert J.A. in Reekie, such relationships need not be premised on marriage or be gender-specific:

[M]arriage itself is not the significant point. The significance lies in the loss of an opportunity to form a permanent interdependency relationship which may be expected to produce financial benefits in the form of shared family income. Such an interdependency might have been formed with a close friend of either sex or with a person with whom a the plaintiff might have lived as husband and wife, but

Ibid. at 331.

lbid.

Supra note 56 at $124-25$.

Ibid. at 125.

This signifies a departure from the "slave market" approach to marriage. See Scarff v. Wilson (1989), 55 D.L.R. (4th) 247.

See Gibson, supra note 69 at 99. 
without any marriage having taken place. Permanent financial interdependency, not marriage, is the gist of the claim. ${ }^{\text {ios }}$

The rationale for recognizing this head of loss in assessing a victim's pecuniary damages is that people benefit financially when they live together, in that they have lower overhead costs, and they derive financial benefits from each other's income and contribution to housework. ${ }^{105}$ The net result may be an improved financial position. It is for this reason that Lambert J.A. stated in Reekie that "lost earning capacity and lost family income are two connected aspects of lost future pecuniary inflow." 106 Consequently, where a person is deprived of this opportunity through the fault of another person, the former deserves to be compensated for this loss. Loss of the opportunity to enter into such a relationship must be considered a capacity that may or may not be exercised by a particular victim, but that decision must be left entirely to the discretion of that individual. It is, therefore, appropriate for courts to consider the impact of the loss of opportunity to form a permanent relationship in damage assessments. The assessment will, of course, vary from case to case depending on statistical evidence and on the situation of the particular individual.

The benefits of this sub-head ought not to be limited to those who were participating in the waged labour force at the time of their injury. In Reekie, Lambert J.A. suggested that the financial implications of the loss of opportunity to benefit from a shared family income should be considered in the context of loss of prospective earnings and not as a separate sub-head. ${ }^{107}$ This would seem to make the claim relevant only in the case of plaintiffs who receive compensation for lost future earnings and not in the case of those in situations similar to the plaintiff in $\mathrm{Knoblauch}^{108}$ who are perceived not to have suffered any loss of earnings. The proper approach would be to consider the implications of loss of an opportunity to form long-term interdependency relationships in the context of loss of working capacity generally. ${ }^{109}$ This would allow for a logical analysis of this claim in cases involving homemakers since they may benefit from their partners' income. It would also entail the recognition of the economic value of homemakers' work to their "family unit," and that their contribution can both improve the overall financial status of the family and benefit all concerned.

It appears that the impact of the loss of opportunity to form a permanent relationship on one's financial status is more relevant in assessing damages for women than for men. Gibson takes issue with limiting the assessment to cases involving female victims as being gendered. She notes that it "takes us back to an era when women's financial and social security in life seemed entirely dependent on marrying." "It is important to note that the financial benefits to be derived from forming a relationship of permanent interdependency are not unique to any one partner or gender. It may be

\footnotetext{
Reekie, supra note 97, at 330-31.

See Cooper-Stephenson \& Saunders, supra note 6 at 337-39; Griffin, supra note 45 at 554.

Reekie, supra note 97 at 336.

Ibid. at 334.

Supra note 20.

See Cooper-Stephenson \& Saunders, supra note 6 at 105, 345-47.

Gibson, supra note 27 at 202.
} 
equally applicable to anyone in such a relationship or likely to enter one, and should, therefore, be considered in assessing the impact of the injury on a plaintiff's financial status in the future, regardless of sex. Nothing precludes the use of this approach in assessing damages for men and boys. Lambert J.A. recognized this possibility when he stated that the head of loss should be referred to as the "lost opportunity of family income."'l' Male victims can also benefit from this approach based on the realization that the loss of an opportunity to form a permanent relationship due to their injury makes them worse off financially, and that they deserve to be compensated for that loss. In Mackenzie v. Van-Kam Freightways, ${ }^{112}$ the British Columbia Supreme Court awarded damages to a male plaintiff under this sub-head. Thus, this head of damages is applicable in assessing pecuniary losses for all personal injury victims regardless of their sex insofar as there is evidence to support it. Perhaps the financial impact of the lost opportunity to benefit from a family income features more prominently in the assessment of damages for female tort victims because of past inequities with respect to the marriage contingency and the desire not to perpetuate this discriminatory practice.

These developments are significant in a number of ways. First, they not only affirm that the loss of opportunity to form a relationship of financial interdependence could result in pecuniary losses, ${ }^{113}$ but also that this is a compensable loss. Second, it is now established that the "marriage contingency" should not be relied upon to reduce damage awards unless the proper evidentiary foundation is present. In Blackstock, Anderson J.A. stated that "unless the court is furnished with adequate statistical information and actuarial advice relating to financial benefits and loss of earning power resulting from marriage, there should be no contingency allowance, upwards or downwards." 114 The weight to be accorded the prospect of the loss or diminution of the opportunity to benefit from a shared family income, if any, depends on the circumstances of each case. In Abbott v. Silver Star Sports, ${ }^{115}$ Wallace J. refused to adjust the plaintiff's award upward or downward based on the loss of opportunity to marry. Wallace J. reasoned that the financial loss of the diminished prospects of marriage to the plaintiff was so nebulous and general that it did not lead to an inference of any economic benefit or detriment to the plaintiff. ${ }^{116}$

The court reached a similar conclusion in Toneguzzo-Norvell. 117 The plaintiff argued before the British Columbia Court of Appeal that the award for future income should be increased to reflect the financial benefits that the plaintiff would have derived from a shared family income. Goldie J.A. conceded that marriage could yield positive financial effects on one's earnings, yet affirmed the trial judge's refusal to consider the

Reekie, supra note 97 at 331 .

(17 April 1990), Victoria Reg. 880871 , Van Reg. 881060 (B.C.S.C.).

This has been recognized elsewhere in the Commonwealth in earlier cases such as Graham v. Fogarthy (1970), 92 W.N. (N.S.W.) 452, cited in Cooper-Stephenson \& Saunders, supra note 6 at 339.

Supra note 96 at 246.

(1986), 6 B.C.L.R. (2d) 83.

Ibid. at 104-105.

(1993), 73 B.C.L.R. (2d) 116. 
impact of positive contingencies (including marriage) on the damage award. This position was supported by the fact that positive contingencies had a zero impact on the award because the pecuniary benefits and losses arising from marriage offset each other, thereby producing no net effect on the award. ${ }^{118}$ This was affirmed by the Supreme Court of Canada in reasons delivered by McLachlin J. ${ }^{119}$

Thus, apparently, the starting point for courts is to assume that the "marriage contingency" would have zero impact on the plaintiff's award unless it is satisfied one way or the other that it should be increased or decreased. Whereas this approach would not necessarily increase an injured woman's award because of a reduction in the prospects of marriage, it certainly guarantees her a starting point of no deduction for the prospects of forming a partnership. It may also have a gender-neutral effect in the sense that marriage will not be considered in the assessment of lost earnings for women just as this factor typically does not have any relevance in cases of injured men. However, this is more likely to result in formal and not substantive equality, particularly when female earning tables are used in computing lost earnings. As mentioned above, female statistics are biased, among other things, because of the perceived negative impact of marriage on women's earning capacity. Not recognizing the impact of financial partnerships on a tort victim's damages could be a convenient way for courts to shy away from increasing awards for lost earnings in the face of uncertainties, rather than giving plaintiffs the benefit of any doubt that exists. This result may be achieved by finding that the evidence presented is inadmissible. In order to achieve gender-neutral results, courts must refrain from using gendered earning statistics.

\section{COMpensation for Impaired Homemaking CAPACity}

In Cairns v. Harris, ${ }^{120}$ the plaintiffs, an elderly couple, sustained injuries as a result of a motor vehicle accident. In assessing their damages, the trial judge awarded the couple $\$ 30,380$ for past and future loss of housekeeping capacity. ${ }^{121}$ On appeal, the couple alleged that the trial judge's assessment of the female plaintiff's inability to perform housekeeping services was flawed. After examining cases on this point, Carruthers C.J.P.E.I., concluded that compensation for impaired homemaking capacity appears to be well settled in Canadian law. This entitles a victim of tortious injury to be compensated for her lost capacity to do housework. From this decision two points are derived: first, that homemaking is recognized as having an economic value capable of quantification; and second, that the impairment of homemaking capacity is a compensable loss. Consequently, persons who experience impairment in their capacity to perform housekeeping tasks are seen to have suffered an economic loss worthy of 
compensation. There are pecuniary and non-pecuniary aspects of the loss of homemaking capacity. ${ }^{122}$

\section{LOSS OF HOUSEKEEPING AbILITIES: A NEW SUB-HEAD IN PERSONAL INJURY CLAIMS}

Judicial recognition of the loss of housekeeping abilities in personal injury claims begins with the important decision of Vancise J.A., writing for the majority of the Saskatchewan Court of Appeal, in Fobel. ${ }^{123}$ The plaintiff in Fobel suffered from chronic pain due to two automobile accidents. The plaintiff's ability to work was substantially reduced. Prior to the accident, the plaintiff was solely responsible for housekeeping, comprising about 40 hours a week in addition to her full-time work in the family business. The plaintiff continued to perform household tasks but with increased difficulty. She hired replacement service on only one occasion. The trial judge awarded damages for pre- and post-trial impairment of housekeeping capacity. The former was considered non-pecuniary because the plaintiff performed the household tasks, although with difficulty. The latter was considered as part of her pecuniary loss, but the judge did not specify the amount awarded for the various components. On appeal, Vancise J.A. affirmed that homemaking services have an economic value capable of quantification. Relying on the English decision in Daly v. General Steam Navigation, ${ }^{124}$ Vancise J.A. held that, though a homemaker does not suffer an actual loss of earnings and may not suffer any pecuniary loss from their inability to perform housekeeping functions, their loss is comparable nonetheless to an employed person who is disabled and who cannot perform their job. ${ }^{125}$ Consequently, the injured homemaker must be compensated in the same way as the person who is disabled and, therefore, is unable to participate in the waged labour force. The fact that the plaintiff did not receive direct financial benefits for homemaking services is irrelevant to the pecuniary nature of this loss. Picard $\mathrm{J}$. accepts this reasoning, stating:

I find that the claim of a homemaker for loss of past and future capacity to carry out her functions is a valid one. It matters not that her work is not carried out in the market place or that she is not paid in money. The reality that her services may be beyond price does not mean they cannot be valued and a loss reflected in an award as damages in the proper case. ${ }^{126}$

Loss of homemaking capacity is currently treated as a new sub-head in the assessment of damages for personal injuries. The rationale for such compensation can be analogized to that of lost earnings. Compensation should involve the recognition of the effect of the injury on the plaintiff's capacity to work in the home. This would be consistent with the compensatory principle in tort that indicates that damages should (as far as money can do this) put plaintiffs in the position they would have enjoyed but

The rationale for this distinction and its consequences for an accident victim will be explored in this section.

123 Supra note 83

[24 [1980] 3 All. E.R. 696 (C.A.) [hereinafter Daly]

125 Ibid. at 395.

126 McLaren, supra note 83 at 21 , para. 124. 
for their injury. The focus on the ability to work rather than on earnings brings this head of damages in line with the lost assets approach. Consequently, compensation for impaired homemaking challenges the dominant judicial approach, which compensates the plaintiff on the basis of lost earnings. For this reason, it would perhaps be appropriate to refer to the head of damages under consideration in this article as the loss of working capacity as suggested by Murphy J. in the Australian case of Sharman v. Evans:

The expression "loss of earning capacity" does not precisely describe this element of loss in its modern application. What is measured is the impairment or destruction of the capacity to engage in work that is economically valuable, whether it would be paid for in money or not. It is a loss of working capacity sometimes referred to as loss of economic capacity. There is a discernible factor of economic loss in loss of ability to do non-earning work of economic value. ${ }^{127}$

Support for this characterization is reiterated by Réaume who notes that compensation for impaired homemaking is justified by the recognition that the plaintiff has lost the ability to engage in economically productive activities, simply referred to as the "capacity to work." ${ }^{28}$ Indeed, compensation for impaired homemaking supports the recognition that a plaintiff should be compensated for incapacity to work regardless of the location of that work.

It is now settled that compensation for lost homemaking capacity is personal to the primary accident victim, just as is loss of income, and not for third parties who would have benefited from the plaintiff's services. ${ }^{129}$ In Fobel, Vancise J.A. noted:

The compensation of a victim for loss of capacity to work in the home was traditionally accomplished by awarding of compensation to a third party (a husband or a family) for loss of the services provided to the third party by the victim. This has never been a satisfactory approach. The loss is personal to the plaintiff. ${ }^{130}$

Historically, the common law recognized the right of husbands to recover monetary damages from a tortfeasor for both pecuniary and non-pecuniary losses resulting from physical injury suffered by their wives. This action originated from the claim of actio per quod consortium amisit by which a husband is compensated for the loss of the wife's domestic services. The action is premised on the medieval perception that wives are their husbands' chattels. The actio per quod, though antiquated and sexist, laid the foundation for compensating accident victims for impaired homemaking capacity. It recognized that, though unpaid, domestic services have economic value that is capable of quantification and warrants compensation when the capacity to perform those services is interfered with by a tortfeasor. In line with the current legal status of

(1977), 138 C.L.R. 563 (H.C. Aus.) [hereinafter Sharman] at 598.

Réaume, supra note 13 at 101 .

See Fobel, supra note 83 at 395; Johnston v. Murchison (1993), 112 Nfld. \& P.E.I.R. 181 at 218 (P.E.I.S.C.(T.D.)); Sharman, supra note 127 at 598; Cooper-Stephenson \& Saunders, supra note 6 at 315-18; R. Graycar, "Compensation for Loss of Capacity to Work in the Home" (1985) 10 Sydney L.R. 528 at 537-40.

Fobel, ibid. 
women, the actio per quod has been abolished in most common law jurisdictions, ${ }^{131}$ but the recognition of the value of housework did not die with it. Rather, the loss in question has been recognized as a loss of the primary accident victim.

Compensation for impaired homemaking ability is considered a new sub-head of damages in personal injury claims separate from the sub-heads of damages both of lost earnings and of cost of future care. However, care must be taken to avoid overlap (for instance as between damages for loss of housekeeping capacity and for cost of future care). ${ }^{132}$ This ensures that not only full-time homemakers can claim compensation for impaired housekeeping ability but also those who, prior to the injury, worked outside the home and performed housekeeping functions as well. As Murphy J. pointed out in Sharman, the loss in question is the victim's capacity to work, wherever that work may be carried out, ${ }^{133}$ and regardless of gender. ${ }^{134}$

The division of homemaking into labour and management components as suggested by Vancise J.A. in Fobel lends further support to this approach. This approach recognizes that, although a woman may not be performing all or part of the labour component because she works outside the home, she could still be compensated for aspects of housekeeping that she is no longer able to perform in addition to future lost earnings. This is a significant inroad for injured women, whether they are part-time or full-time homemakers. It recognizes that homemaking is productive labour. As well, it gives judicial recognition to the double-day lives of many women by ensuring that those who work outside the home (who are, therefore, entitled to future earnings) are also compensated for the work that they can no longer perform in the home. Further, homemaking is no longer considered solely as an amenity from which women derive inherent satisfaction. Rather, it acknowledges that a person may derive satisfaction from whatever they do without compromising the economic value of their work. The focus on capacity to work avoids the public/private dichotomy discussed above by recognizing the value of women's work wherever it occurs.

Therefore, it is immaterial whether the monies so awarded are used to engage replacement services. It is not a prerequisite for awarding damages that the plaintiff must satisfy the court of an intention to procure substitute services for the future loss of housekeeping capacity. This is because the capacity in question is considered an asset and the plaintiff is compensated for the loss of this asset. This leaves the plaintiff entirely free to struggle in the performance of these tasks if she so chooses, or to benefit from gratuitous services if she is so fortunate.

131 For example, see the Law and Equity Act, R.S.B.C. 1996, c. 253, s. 63.

132 See Cooper-Stephenson \& Saunders, supra note 6 at 312.

13. Sharman, supra note 127 at 598.

13. In McLaren, supra note 83 at 22, para. 126, Picard J. emphasized that the claim for impaired housekeeping is not restricted to women. She noted that there are men who carry out housekeeping functions and who deserve to be compensated when the capacity to do so has been impaired. In particular, she makes reference to men who are single parents and others who perform such functions pursuant to their family arrangements. 


\section{ASSESSING THE VALUE OF IMPAIRED HOUSEKEEPING CAPACITY}

Case law suggests that pre-trial and future loss of homemaking capacity must be assessed separately. In Fobel, Vancise J.A. commented that "[i]t would have been preferable for the trial judge to set out in the award of general damages the amount awarded for pecuniary loss and the non-pecuniary pre-trial loss of housekeeping capacity." 35 The Canadian position has been influenced by the decision of the English Court of Appeal in Daly. ${ }^{136}$ In that case, the plaintiff homemaker was seriously injured and as a result was unable to perform all of her accustomed tasks. She continued to perform all of these tasks with some difficulty and with help from family members. The court held that the assessment of damages for her pre-trial and future loss of housekeeping capacity must be considered separately.

Loss of homemaking capacity may be assessed as part of special or general damages. Special damages are specific, pre-trial pecuniary losses of an accident victim. They may include lost earnings, cost of care, and other incidental expenses. Special damages must be specifically pleaded and proved. They are generally capable of fairly exact calculation. On the other hand, general damages consist of future pecuniary losses and all non-pecuniary losses.

In McCallum v. Ritter, ${ }^{137}$ the issue before the Saskatchewan Court of Appeal was whether the plaintiff's pre-trial loss of housekeeping capacity was to be considered pecuniary or non-pecuniary. In that case, the plaintiff's housekeeping capacity had been impaired because of her injury. The plaintiff's husband performed the housekeeping tasks that she had been accustomed to doing without remuneration. The defendant argued that the housekeeping tasks carried out by the plaintiff's partner should be compensated as general damages rather than as special damages. The court held that since the plaintiff's husband performed the tasks that she could not, it was a matter of substituted performance and must, therefore, be treated as special damages.

Therefore, pre-trial loss of housekeeping ability will be characterized as special damages where the victim procured substitute services. Characterizing pre-trial substitute performance as special damages poses no problem when it involves out-ofpocket expenses on the part of the plaintiff. Presumably, the rationale for maintaining this categorization, even for gratuitous services, is because it is known that the household tasks in question (which the plaintiff could not perform because of the tortious injury) were done by someone else. As well, the value of those services can readily be ascertained by reference to their market value. It is immaterial that the plaintiff did not incur out-of-pocket expenses to obtain those services as long as someone else carried out the tasks that the plaintiff was accustomed to performing. In McCallum, Bayda C.J.S. pointed out:

137 (1990), 72 D.L.R. (4th) 49 (Sask. C.A.) [hereinafter McCallum]. 
It is not whether money was paid for services that controls whether the damages are characterized as special or general. It is instead whether the claim relates to difficulty in actual performance or the need for substituted performance (paid or gratuitous). The former is general; the latter special. ${ }^{138}$

Allowing recovery for voluntary housekeeping services from which an accident victim has benefited is in line with principles relating to collateral benefits. There is ample authority indicating that a plaintiff can recover special damages for services voluntarily rendered by third parties, even in the absence of a legal or moral obligation to pay for the services. ${ }^{139}$

Pre-trial loss of homemaking capacity is characterized as a non-pecuniary loss of amenity under general damages when the plaintiff receives no substitute service and performs the tasks herself with difficulty (as in Fobel ${ }^{140}$ ), or when housework remains undone. In those cases, compensation for impaired housekeeping capacity is considered a loss of amenity to the extent that the plaintiff is no longer able to perform those tasks, or has to do them with difficulty. The designation of this loss as non-pecuniary, however, should not affect damages that are recoverable for traditional non-pecuniary damages, which includes pain and suffering and loss of amenities. As such, compensation for this loss of amenity ought to be free from the strictures of traditional non-pecuniary damages discussed above. The preferred method is to consider nonpecuniary loss of housekeeping capacity as a sub-head under general non-pecuniary damages. ${ }^{141}$ The categorization of pre-trial impairment of housekeeping capacity as non-pecuniary should not be perceived as devaluing women's work in the home. In fact, it recognizes that injured women who continue to perform household tasks with discomfort or those who cannot perform them at all have suffered a compensable loss. Further support for this position can be found in the method of assessment for this loss of amenity, which is achieved by referring to the current market value of those

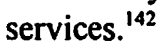

It follows from the foregoing discussion that when a plaintiff performs some household tasks with difficulty, and receives gratuitous help with those tasks that she can no longer perform because of the injury, compensation for pre-trial impairment of housekeeping capacity must be partly general and partly special. The general damages component represents compensation for the plaintiff's "pain and suffering and loss of amenity caused by the additional difficulty she had in doing her housekeeping work." ${ }^{143}$ The value of gratuitous services rendered to the plaintiff should be

138 Ibid. at 55 [emphasis in original].

139 See Cooper-Stephenson \& Saunders, supra note 6 at 173, 177-80.

141 As pointed out earlier, the plaintiff in Fobel, employed substitute service on only one occasion at the cost of $\$ 65$. Consequently, she virtually performed the household functions on her own.

is1 See Fobel, supra note 83 at 421-24 where Vancise J.A. considered traditional non-pecuniary loss - pain and suffering and loss of amenity - separate from pre-trial loss of housekeeping capacity. See also Graycar, supra note 129 at 551 .

142 See below for a discussion of the method of valuation.

143 Daly, supra note 124 at 701 per Bridge L.J. This pain and suffering is not treated as a separate head of damage. Rather, it is a factor to be considered in assessing the victim's non-pecuniary losses. 
compensated by way of special damages. Because of this reasoning, the decision in Johnston v. Murchison ${ }^{144}$ (regarding the compensation for pre-trial loss of homemaking capacity) is questionable.

In Johnston, the plaintiff, whose housekeeping capacity had been impaired by an accident, struggled prior to the trial to perform certain household tasks and received help from family members with other household tasks. There was no evidence that the plaintiff paid, or would pay, for the services. Matheson J. proceeded to assess pre-trial loss of housekeeping capacity as a loss of amenity. The assessment vis-à-vis homemaking undertaken by the plaintiff subsequent to her injury was rightly found to be a non-pecuniary loss. However, housekeeping services provided by family members did not qualify as a non-pecuniary loss. This was a case of substituted service and should thus have been considered part of special damages. ${ }^{145}$ In the end, however, the distinction between pecuniary and non-pecuniary loss of past housekeeping capacity may not be too important as they are both assessed based on the replacement cost of those services. In Fobel, the Saskatchewan Court of Appeal recognized that the replacement cost is an important, though not the sole factor, in assessing non-pecuniary loss of housekeeping capacity. In spite of Bayda C.J.S.'s admonition that pre-trial nonpecuniary loss of housekeeping should not be assessed by reference to the replacement costs of those services, ${ }^{146}$ recent judicial opinion seems to favour the reliance on replacement cost as the exclusive measure for quantifying this loss. ${ }^{147}$

Future loss of housekeeping capacity is considered part of a tort victim's pecuniary losses and is assessed in the context of general damages. The value of the plaintiff's loss is based on the estimated cost of replacement services for the expected period of disability. This gives further support to the idea that compensation in this area is for the economic value of the activities that the accident victim is no longer able to engage in as a result of the injury. This result is achieved regardless of the plaintiff's earnings. The issue at stake is the victim's incapacity to work. It is therefore submitted that this head of damages should be characterized as incapacity to work. Under this rubric, there could be sub-heads (including future earnings and loss of housekeeping, depending on the evidence admitted and the situation of the particular individual). This categorization brings compensation for impaired housekeeping into the mainstream of the law of damages. Almost every accident victim could benefit from this sub-head as long as they satisfy the court that they performed or would have engaged in housekeeping functions. It also means that young victims who were likely to have undertaken housekeeping trial judge's assessment of loss of housekeeping capacity on appeal. See Johnston v. Murchison (1995), 127 Nfld. \& P.E.I.R. 1 at 23-24, paras. 83-84 (P.E.I.C.A.).

This was not the finding of the court, however, because there was no evidence of payment for those services: Johnston, ibid. at 218, para. 171. See also Hilliard v. Grabinski (1998), 221 A.R. 201 at 238 , where Lee J. seems to have lumped all pre-trial loss of housekeeping capacity as a loss of amenity. quantify a victim's non-pecuniary loss of housekeeping capacity by reference to what it would cost to employ such help when the person had not used substitute service. 
tasks should receive compensation under this sub-head in the same way that they would for loss of earnings.

Clearly, this analysis transcends the public/private dichotomy by recognizing the value of work wherever it is performed. However, assessing the value of housekeeping by referring to its market value is problematic. This approach relies on public tools to assess the value of work performed in the home. It presupposes that, although housekeeping functions are said to have an economic value in and of themselves, they are, however, not capable of valuation on their own merit. There is still a danger of under-compensation. Not all of the functions performed by accident victims will have a market value. As well, the traditionally low wages for domestic services is a further bar to just compensation for impaired housekeeping capacity. It will take a change in the perception of the economic value of domestic services to remedy the undervaluation of women's work in the home, and ultimately, to ensure fair compensation for impaired housekeeping capacity. The need for this change is also supported by the demystification of the myth that women are secondary wage earners. Today, a woman's income is as crucial to the running of the family as is a man's income. There is, therefore, no legal or moral justification for giving women depressed awards for their inability to work due to tortious injury.

\section{CONClusion}

This article has explored why the assessment of damages for female tort victims is perceived as discriminatory against women, and the judicial efforts to eliminate gender bias in assessing compensation for impaired working capacity. Achieving fair compensation for female tort victims requires the deconstruction of myths about women and women's work as well as about the implications of marriage on a woman's financial situation. Courts have used one of two methods to assess the value of a victim's impaired working capacity. Though the use of female earning tables with the possibility of top-up is intended to result in just compensation, it is not entirely satisfactory. Among other things, its reliance on female earning statistics perpetuates rather than challenges discriminatory pay structures for men and women. It also leaves intact the unfavourable assumptions about women's work. As well, the use of female earning tables with the possibility of upward adjustment is likely to result in differential outcomes even for similarly-situated tort victims because the result in each case depends on the strength of evidence presented to the court. The use of male earning statistics is not entirely satisfactory, either. This method of valuation for just compensation for an injured woman's incapacity to work is problematic because it is based on the assumption that the woman's attachment to the labour force as well as her characteristics and abilities would have made her probable earnings comparable to her male counterparts. As such, courts are less likely to resort to male earning statistics in assessing damages for victims with no prior work history or for those who have not yet exhibited personal traits that could guide the court's assessment of their future earnings.

Both methods of valuation are not satisfactory from a feminist perspective because of their reliance on gender in assessing the value of a victim's loss. The diversity in the backgrounds and characteristics of tort victims means that no one method of valuation 
for incapacity to work can adequately capture the losses of an accident victim. The best indicators of a person's loss should be their individual characteristics and capabilities, not their gender. However, personal characteristics and capabilities should be assessed in a fair manner so as not to replicate the historical inequities against certain groups of women that are prevalent in today's society. When it is not possible to assess victims' losses based on their individual characteristics and capabilities (such as in the case of very young tort victims) then average male earnings ought to be the basis for assessing the value of a female tort victim's impaired working capacity. In so doing, courts must be careful not to apply contingency deductions that are already reflected in average earnings.

Courts have recognized that the benefits of shared family income should not be limited to those who participated in the waged labour force prior to their injury. All women should benefit from shared family income whether or not they received remuneration for their work, and regardless of where their work takes place. Compensation for impaired homemaking should be considered in the context of impaired working capacity generally, thus making it available not just for victims who engaged in housework prior to the injury, but also to those, including young victims, who would likely have performed some housework but for their injury. 